\title{
IMPLEMENTATION OF QUALITY BY DESIGN (QBD) APPROACH IN FORMULATION AND DEVELOPMENT OF RITONAVIR PELLETS USING EXTRUSION SPHERONIZATION METHOD
}

\author{
SATISH K. MANDLIK*, PAYAL P. AGARWAL, HARSHAL P. DANDGAVHAL \\ STES's Sinhgad College of Pharmacy Vadgaon (Bk), SP Pune University, Pune, India \\ Email: satish4004@gmail.com \\ Received: 23 Aug 2019, Revised and Accepted: 08 Nov 2019
}

\begin{abstract}
Objective: Ritonavir is an antiretroviral drug used for HIV-AIDS treatment. The purpose of this research work was to implement the quality by design (QbD) approach in formulation of ritonavir sustained-release pellets by industrially applied extrusion spheronization technique.

Methods: Pellets were prepared by extrusion spheronization method and evaluated for their physicochemical properties. Initially, on the basis of prior knowledge Quality Target Product Profile (QTTP) element was identified and further Critical Quality Attributes (CQA) elements were defined. Risk assessment (RA) was done by two tools as failure mode and effect analysis (FMEA) and fishbone diagram (Ishikawa plot). Placket Burman design was implemented as a screening design using seven high-risk factors (spheronization speed, spheronization time, extrusion speed, drying method, PVP K 30, cross povidone, and solvent). Optimization study was done by $2^{3}$ full factorial design with three critical factors as (spheronization speed, extrusion speed and PVP K 30). The in vitro drug release was studied in both gastric and intestinal fluids for $12 \mathrm{~h}$ using USP I apparatus. Control space was established for the sustained release pellets.
\end{abstract}

Results: Among all batches obtained in $2^{3}$ full factorial design, batch R7 was found to be effective with carr's index value of 5.281 , percentage yield of $69.6 \%$, time required to release $50 \%$ drug was $8 \mathrm{~h}$ and percent drug release after $12 \mathrm{~h}$ was found $83.132 \%$, R7 batch was selected as optimized batch. Statistical analysis showed model terms were significant.

Conclusion: We can conclude that; sustained-release pellets of ritonavir were successfully designed using QbD approach.

Keywords: Extrusion, Spheronization, Pellets, Quality by Design (QbD), Plackett-Burman Design, Optimization

(C) 2020 The Authors. Published by Innovare Academic Sciences Pvt Ltd. This is an open-access article under the CC BY license (http://creativecommons.org/licenses/by/4.0/) DOI: http://dx.doi.org/10.22159/ijap.2020v12i1.35453. Journal homepage: https://innovareacademics.in/journals/index.php/ijap

\section{INTRODUCTION}

Quality by design (QbD) is the combination of three International Conferences of Harmonization Guidelines i.e. (Q8) pharmaceutical development, (Q9) quality risk management and (Q10) pharmaceutical quality system [1]. QbD is defined as "A systematic approach to development that begins with predefined objectives and important product and process understanding and process control, based on robust supporting science and quality risk management" [2]. The aim of $\mathrm{QbD}$ is to build the product quality process than the simple test process which is based on four important elements: (i) Identification of Quality Target Product Profile (QTPP), (ii) Determination of Critical Quality Attributes (CQAs) by Critical Process Parameters (CPP), Critical Material Attributes (CMA). (iii) Assessment of risk by Failure Mode Effect Analysis (FMEA) and Ishikawa Plot (Fishbone Diagram). (iv)Establishment of Design Space (DS) and Control Space (CS) [3, 4]. Design Space (DS) is defined as "The multidimensional combination and interaction of input variables and process parameters that have been demonstrated to provide assurance of quality" $[5,6]$.

Pellets are defined as spherical, free-flowing granules with a narrow size distribution typically varying between 500 to $1500 \mu \mathrm{m}$ for pharmaceutical applications. Sustained release drug delivery system in form of pellets formulation comes up with plenty of advantages like less gastric irritation, maximized drug absorption, improve drug bioavailability, improve flow properties, reduce drug plasma fluctuation and reduce potential side effects, Wang et al. [7]. Extrusion spheronization technique was used to prepare pellets. The critical factor that impact extrusion spheronization are spheronization speed, spheronization time, extrusion speed, drying method, PVP k30, crosspovidone, solvent, mixing time, spheronization load and extruder time all these factors were evaluated as per QbD principles, Sirisha et al., Kandukuri et al. [8, 9].

Ritonavir is an antiretroviral drug used for HIV-AIDS treatment. Sustained-release oral delivery systems are designed to achieve therapeutically effective concentration of drug in systemic circulation over an extended period of time. Ritonavir is 1,3-thiazol-5-yl methyl N-
[(2S,3S,5S)-3-hydroxy-5-[(2S)-3-methyl-2-\{[methyl(\{[2-(propan-2-yl)-1,3thiazol 4yl] methyl\})carbamoyl]amino\}butanamido]-1,6-diphenyl-hexan2-yl]carbamate. Ritonavir is BCS Class II drug with half-life of 3-5 h. The solubility of drug is poor in gastric $\mathrm{pH}$, Patil et al., Desai et al. $[10,23]$. The aim of this research work was to apply QbD approach involving risk assessment and DoE to ritonavir sustained-release pellets by using an extrusion-spheronization method. The study was further continued by defining the QTPP and CQAs as preliminary study [11]. Risk assessment (FMEA, fishbone diagram) to identify the critical parameter such as CPPs (critical process parameters) and CMAs (critical material attributes) [12]. Placket-Burman design was implemented as screening design. $2^{3}$ factorial design was implemented as optimization design in response surface method (RSM) study. DS was established following the obtained response surface, control space (CS) was further achieved $[13,14]$.

\section{MATERIALS AND METHODS}

Material

Ritonavir was obtained from Mylan lab (Sinner, Nashik), Polyoxyethylene 10 lauryl ether as a solubilizer purchased from Venus Ethoxyether Pvt. Ltd (Goa, India) Polyvinyl pyrrolidone (PVP k-30), Crospovidone, Lactose, Aerosil 200 were obtained from Sinhgad College of Pharmacy, (Pune, India)

\section{Experimental method}

Identification of quality target product profile (QTPP) and to define critical quality attributes (CQA) elements

QTPP elements for ritonavir pellets were identified based on a thorough literature survey and prior knowledge. From QTPP elements CQA elements were defined.

\section{Risk assessment}

The fish-bone diagram was considered as to identify the potential risks factor of formulation and development, which affects \% drug release, \% yield, and flow properties to identified as the CQAs. Based 
on prior knowledge, the failure mode and effect analysis (FMEA) method were further applied in the initial risk analysis of the parameters of the pellets. Each variable was scored in terms of severity (S), detectability (D) and probability (P). All the more comprehensively, Severity is the wellbeing and viability of the last item. Detectability characterized that a disappointment mode can be recognized. The last parameter probability is considered as the event likelihood or the probability of a disappointment. For each hazard, S, D, P scores were increased together to deliver a "Risk Priority Number" (RPN). The RPN limit was set at 15;any procedure parameter with a RPN 15 was viewed as a potential basic factor which sways on CQAs and in item security and viability, while factors with a lower RPN can be disposed of from further investigation $[7,11]$.

\section{Establishment of design space}

Design space was established by using placket-burman design as screening design and $2^{3}$ Factorial Design as an optimization design.

\section{Preparation of ritonavir pellets by extrusion spheronization}

Ritonavir pellets were prepared by the method of extrusion spheronization. Ritonavir and various excipients such as PVP K 30 lactose, crospovidone and aerosil 200 were mixed in mortar pestle. The granulating liquid was added slowly to the powder blend, which was then mixed until a homogeneous, cohesive wet mass was obtained. The resulting wet mass was extruded at a mesh of size 1.5 $\mathrm{mm}$. Then spheronization was performed in a spheronizer with a rotating chequered plate with cross-hatch geometry (size-3.25 mm) for $3 \mathrm{~min}$. Then prepared pellets were air-dried [15].

\section{Plackett-Burman design as screening design}

According to the risk assessment results, Plackett-Burman study was used to screen 7 critical parameters that may impacts on process and formulation development. The sustained release pellets which contained ritonavir $200 \mathrm{mg}$, lactose as diluent which was $55 \%$ and Aerosil 200 as glidant $1.44 \%$ of the amount was kept constant. 7 critical parameters which are, $\mathrm{X}_{1}$ : Spheronization speed; $\mathrm{X}_{2}$ : spheronization time; $\mathrm{X}_{3}$ : Extrusion speed; $\mathrm{X}_{4}$ : drying method; $\mathrm{X}_{5}$ : $\mathrm{PVP}$ K30 conc.; $X_{6}$ : Crosspovidone conc.; $X_{7}$ : solvent were evaluated at low $(-1)$ and high $(+1)$ levels were. The responses were carr's index $\left(\mathrm{Y}_{1}\right),\left(\mathrm{Y}_{2}\right) \%$ yield, $\left(\mathrm{Y}_{3}\right)$ time required to release $50 \%$ drug and $\left(\mathrm{Y}_{4}\right) \%$ of drug release in $12 \mathrm{~h}$, Sona et al. [13].

\section{$2^{3}$ full factorial design as optimization design}

Depend on the results of the Plackett-Burman screening study. Three supercritical parameters were evaluated at 2 levels as high [1] and low [-1]. Three critical parameters selected were $\mathrm{X}_{1}$ : Spheronization speed; $\mathrm{X}_{2}$ : Extrusion speed; $\mathrm{X}_{3}$ : PVP K30 concentration. Total 8 batches were prepared. The responses were carr's index $\left(\mathrm{Y}_{1}\right),\left(\mathrm{Y}_{2}\right)$ \% yield, $\left(\mathrm{Y}_{3}\right)$ time required to release $50 \%$ drug and $\left(Y_{4}\right) \%$ of drug release in $12 \mathrm{~h}$.

\section{Evaluation of prepared pellets}

\section{Flow properties of pellets}

The flow properties of prepared pellets were evaluated by parameters like tapped density, carr's index, Hausner's ratio, angle of repose.

\section{Particle size and spherical shape}

For determination of particle size of pellets by using Digital Vernier caliper was used. About 20 pellets particle from the representative sample were randomly taken, and pellets particle size was measured and the Average particle size was calculated.

\section{Percentage yield}

Percentage yield Determine whether the preparation procedure chosen for incorporating a drug into the polymers is efficient. The raw materials, amount of active compound was weighed and yield was determined by weighing the ritonavir pellets and then finding out the percentage yield with respect to the weight of the input materials, i.e., the weight of drug and polymers used. The formula for calculation of $\%$ yield is as follows:

$$
\% \text { yield }=\frac{\text { wt of pellets }}{\text { wt of drug }+ \text { wt of polymer }} \times 100
$$

\section{Pellets hardness}

About 20 pellets particle from the representative sample were randomly taken, and pellets hardness were measured using digital pellets hardness tester. Average hardness was calculated.

\section{In vitro drug release studies}

The in vitro release of the drug from pellets of all formulation batches were performed using USP apparatus type I (basket) Lab India DS 8000, at $50 \mathrm{rpm}$. The dissolution media was maintained at $37 \pm 2{ }^{\circ} \mathrm{C}$. "0" size capsules filled with pellets were tested for drug release for $12 \mathrm{~h}$ in $0.1 \mathrm{~N} \mathrm{HCl}(900 \mathrm{ml})$ by adding polyoxyethylene 10 lauryl ether for $1^{\text {st }}$ two hrs. Then the dissolution medium was changed to phosphate buffer $(\mathrm{pH} 7.4)$ by adding $10 \mathrm{M}$ of potassium di-phosphate $8 \mathrm{ml}$ in $0.1 \mathrm{~N} \mathrm{HCL}$, and drug release was studied further for $12 \mathrm{~h}$. The amount of drug released at each time interval was determined by UV spectrometer at $245 \mathrm{~nm}$ [21].

\section{RESULTS AND DISCUSSION}

\section{QTPP of ritonavir and CQAs identification}

\section{Study of QTPP for the formulation}

The QTPP contains a prospective summary of the quality characteristics of a drug product that will be ensure the desired quality, safety and efficacy of the drug product [12]. QTPP was performed on ritonavir drug pellets. QTPP for ritonavir pellets were listed in table 3.

\section{Risk assessment}

Risk assessment aims to obtain all the potential high impact factors which will be subjected to study to establish a product or process design space. A fishbone diagram was preformed according to ICH Q8 R2, to identify critical process parameters and critical material attributes of CQAs that affects the quality of pellets shown in fig. 1. The first step in the risk assessment was to systematically gather up all the possible factors that could influence product quality. Based on the literature data, previous study experiences. After gathering all possible factors secondary risk assessment was done by failure mode and effect analysis (FMEA) as shown in fig. 2.

\section{Table 1: QTPP for ritonavir sustained-release pellets}

\begin{tabular}{lll}
\hline QTPP elements & Target & Justification \\
\hline Dosage form & Sustained released pellets in capsule & Pharmaceutical equivalence requirement \\
Route of administration & Oral & Pharmaceutical equivalence requirement: Same route of administration \\
Dosage strength & $200 \mathrm{mg}$ & Pharmaceutical equivalence requirement: Same strength \\
Stability & At least 24 mo shelf life at room temp & Equivalent to or better than RLD shelf-life \\
Drug product quality & Physical attributes & Pharmaceutical equivalence requirement: Meeting the same compendial or \\
attributes & other applicable (quality) standards (i.e., identity, assay, purity, and \\
& Identification & quality) \\
& Assay & \\
& Content uniformity & \\
& Drug release & \\
& Melting point & \\
& Flow properties & \\
& Water content & \\
\hline
\end{tabular}

Based on scientific prior knowledge and preliminary studies from the initial risk assessment of formulation variables, the flow properties as carr's index, \% yield, the time required to release $50 \%$ drug and $\%$ of drug release in $12 \mathrm{~h}$ were selected as critical quality attributes [12]. 


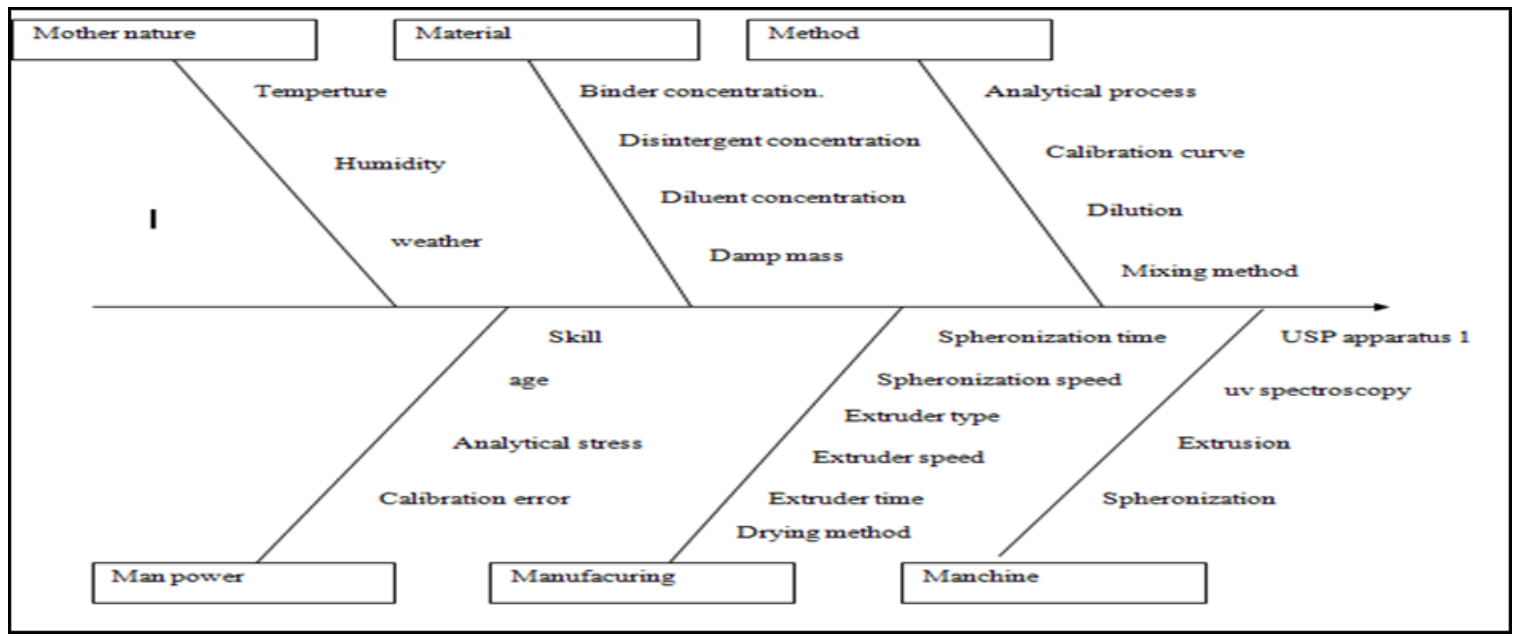

Fig. 1: Fish-bone diagram illustrating factors that may have an impact on CQAs

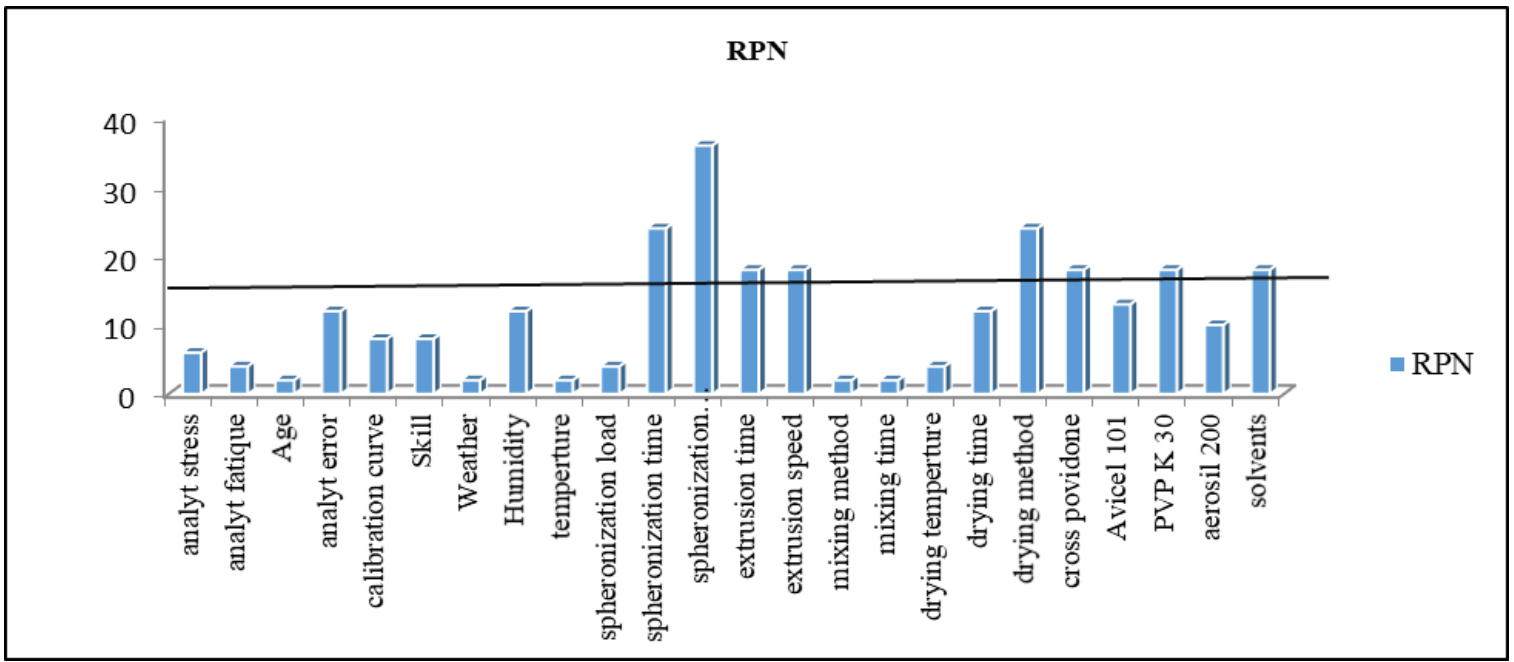

Fig. 2: RPN score after FMEA risk assessments any variable above the RPN threshold of 15 was considered as a potential risk factors

After risk assessment, further design space was established by using placket-burman design as screening design and $2^{3}$ Factorial Design as an optimization design.

\section{Plackett-burman design as a screening design}

Eight batches were formulated (PB1-PB8) containing various ratios of lactose and PVP K 30 and crospovidone as shown in table 2. Out of all these batches, five batches were excluded from the study as no satisfactory results were obtained from them. Then the remaining three batches as PB3, PB6 and PB8 were selected for studies. The
PB3, PB6 and PB8 batches were studied for the particle size analysis, bulk density, tapped density, carr's index and \% drug release. The results showed that the percent drug release of Ritonavir from PB3, PB6 and PB8 formulations under acidic medium after $2 \mathrm{~h}$ was $20.191 \pm 2.0 \%, 16.203 \pm 1.2 \%$, and $17.481 \pm 2.3 \%$ respectively and $\mathrm{pH}$ 7.4 after $12 \mathrm{~h}, \quad 77.467 \pm 4.2,80.467 \pm 5.1 \%$ and $80.743 \pm 5.3 \%$ respectively as shown in table 3. As PB8 formulation had shown better results of dissolution than that of all batches; therefore, PB8 batch was selected for further studies. Percent drug release after 12h for batch PB1 to PB8 is shown in fig. 3 and fig. 4.

Table 2: Plackett-burman design as a screening design

\begin{tabular}{|c|c|c|c|c|c|c|c|c|c|c|c|}
\hline Runs & $\mathrm{X}_{1} \mathbf{r p m}$ & $\mathrm{X}_{2}$ min & $\mathrm{X}_{3} \mathrm{rpm}$ & $\mathbf{X}_{4}$ & $\mathrm{X}_{5} \%$ & $\mathrm{X}_{6} \%$ & $\mathbf{X}_{7}$ & $\mathbf{Y}_{1} \%$ & $\mathbf{Y}_{2} \%$ & $\mathbf{Y}_{3} \mathbf{h}$ & $\mathrm{Y}_{4} \%$ \\
\hline PB1 & 900 & 10 & 45 & Room & 1.5 & 4.5 & Ethanol & $10.45 \pm 1.2$ & $45.56 \pm 3.1$ & $8.30 \pm 1.4$ & $57.874 \pm 3.1$ \\
\hline PB2 & 1200 & 10 & 45 & Oven & 3.0 & 2.5 & Ethanol & $13.34 \pm 0.8$ & $43.78 \pm 2.4$ & $9.30 \pm 0.8$ & $54.363 \pm 2.8$ \\
\hline PB3 & 1200 & 20 & 45 & Oven & 1.5 & 4.5 & $\mathrm{Aq}$ & $0.981 \pm 0.6$ & $55.78 \pm 3.8$ & $7.0 \pm 0.7$ & $71.666 \pm 4.1$ \\
\hline PB4 & 900 & 20 & 55 & Oven & 1.5 & 2.5 & $\mathrm{Aq}$ & $15.87 \pm 0.9$ & $56.79 \pm 2.9$ & $8.30 \pm 1.1$ & $56.786 \pm 2.9$ \\
\hline PB5 & 1200 & 10 & 45 & Room & 1.5 & 2.5 & $\mathrm{Aq}$ & $10.87 \pm 0.2$ & $54.83 \pm 1.9$ & $8.30 \pm 1.7$ & $66.958 \pm 3.5$ \\
\hline PB6 & 900 & 20 & 45 & Room & 3.0 & 2.5 & $\mathrm{Aq}$ & $1.042 \pm 0.1$ & $50.37 \pm 2.1$ & $6.30 \pm 2.0$ & $75.795 \pm 3.7$ \\
\hline PB7 & 900 & 10 & 55 & Oven & 3.0 & 4.5 & Ethanol & $11.45 \pm 1.3$ & $42.73 \pm 2.5$ & $8.30 \pm 1.1$ & $56.398 \pm 2.4$ \\
\hline PB8 & 1200 & 20 & 55 & Room & 3.0 & 4.5 & $\mathrm{Aq}$ & $3.714 \pm 0.5$ & $61.68 \pm 2.6$ & $6.0 \pm 0.7$ & $76.832 \pm 3.9$ \\
\hline
\end{tabular}

$\mathrm{X}_{1}$ : Spheronization speed; $\mathrm{X}_{2}$ : spheronization time; $\mathrm{X}_{3}$ : Extrusion speed; $\mathrm{X}_{4}$ : drying method; $\mathrm{X}_{5}$ : PVP $\mathrm{K} 30$ conc.; $\mathrm{X}_{6}$ : Crosspovidone conc.; $\mathrm{X}_{7}$ : solvent. The response carr's index $\left(\mathrm{Y}_{1}\right),\left(\mathrm{Y}_{2}\right) \%$ yield, $\left(\mathrm{Y}_{3}\right)$ time required to release $50 \%$ drug and $\left(\mathrm{Y}_{4}\right) \%$ of drug release in $12 \mathrm{~h}$. Data are presented as mean \pm SD $(n=3)$ 
Table 3: Evaluation of three screening batches as PB3, PB6 and PB8

\begin{tabular}{|c|c|c|c|c|c|c|}
\hline Trial batches & $\begin{array}{l}\text { Particle size } \\
(\mathrm{mm})\end{array}$ & $\begin{array}{l}\text { Bulk density } \\
\left(\mathrm{gm} / \mathrm{cm}^{3}\right)\end{array}$ & $\begin{array}{l}\text { Tapped density } \\
\left(\mathrm{gm} / \mathrm{cm}^{3}\right)\end{array}$ & $\begin{array}{l}\text { Carr's index } \\
(\%)\end{array}$ & $\begin{array}{l}\% \text { D. R } \\
0.1 \text { N HCL (2h) }\end{array}$ & $\begin{array}{l}\text { \% D. R pH7.4 } \\
\text { (12h) }\end{array}$ \\
\hline PB3 & 1.02 & 0.706 & 0.713 & $0.981 \pm 0.1$ & $20.191 \pm 2.0$ & $77.467 \pm 4.2$ \\
\hline PB6 & 0.98 & 0.854 & 0.863 & $1.042 \pm 0.2$ & $16.203 \pm 1.2$ & $80.467 \pm 5.1$ \\
\hline PB8 & 0.97 & 0.777 & 0.807 & $3.714 \pm 0.2$ & $17.484 \pm 2.3$ & $80.743 \pm 5.3$ \\
\hline
\end{tabular}

Data are presented as mean $\pm \mathrm{SD}(\mathrm{n}=3)$

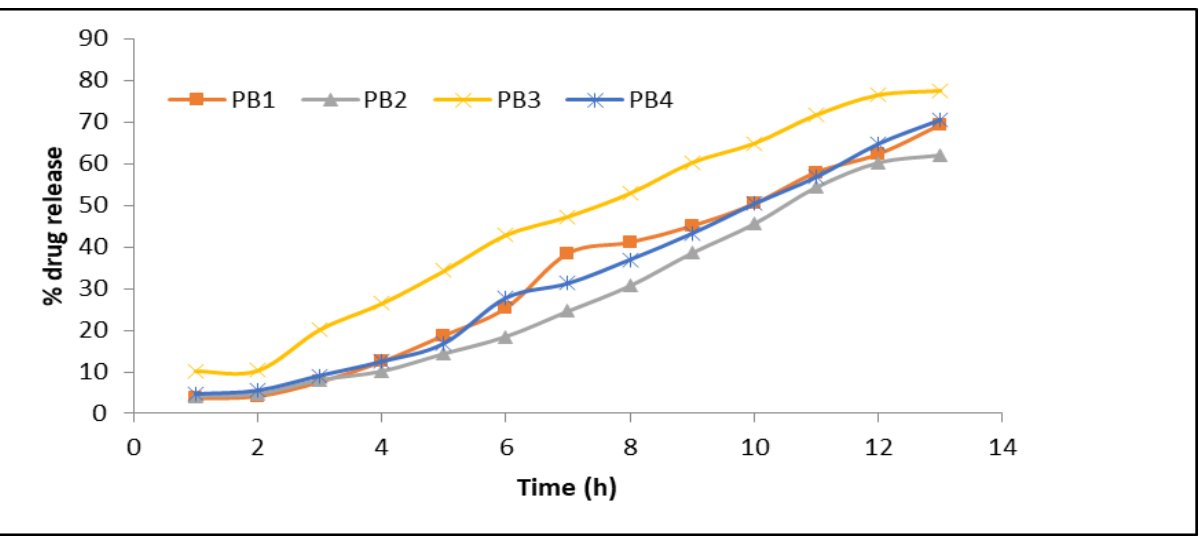

Fig. 3: \% drug release in 12h (PB1-PB4), data are presented as mean $\pm S D(n=3)$

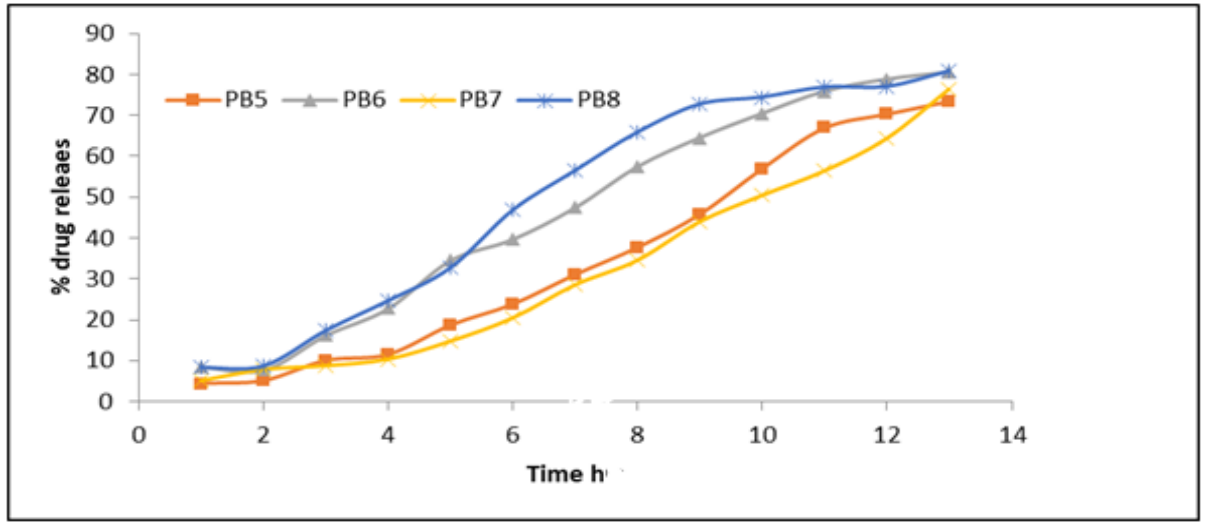

Fig. 4: \% drug release in 12h (PB5-PB8), data are presented as mean $\pm S D(n=3)$

\section{$2^{3}$ full factorial design as optimization design}

$2^{3}$ factorial design studies the response surface methodology (RSM) of various variables with help of design expert 8 applied on the optimal ritonavir sustained-release pellets using extrusion spheronization. Results of the factorial design are shown in table 4. Carr's index $\left(Y_{1}\right)$ was found in range of $0.368 \pm 0.0$ to $5.281 \pm 0.2$, percent yield $\left(\mathrm{Y}_{2}\right)$ from $48 \pm 2.4 \%$ to $69.6 \pm 3.4 \%$, the time required to release $50 \%$ drug $\left(\mathrm{Y}_{3}\right)$ ranges from 6.30 to $8 \mathrm{~h}$ and percent drug release after $12 \mathrm{~h}$ from $\left(\mathrm{Y}_{4}\right) 73.446 \pm 4.1 \%$ to $83.142 \pm 4.19 \%$. The statistical analysis results were studied by using Design Expert 8 software. 3FI model was found to be best fit model and polynomial equation shows which variables had the most potential effect on the response. Percent drug release for batches R1 to R8 is shown in fig. 5 and fig. 6 . It was differentiated that from all the above batches R7 batch had shown maximum percentage yield of $69.6 \pm 3.4 \%$ and highest drug release of $83.142 \pm 4.19 \%$ after $12 \mathrm{~h}$. So that R7 batch was considered as optimized batch.

Table 4: $2^{3}$ full factorial design as an optimization design

\begin{tabular}{|c|c|c|c|c|c|c|c|c|c|c|}
\hline \multirow[t]{2}{*}{ Batches } & \multicolumn{2}{|c|}{ Factors } & \multicolumn{2}{|r|}{$\mathbf{X}_{1}$} & \multirow{2}{*}{$\begin{array}{l}X_{2} \\
\text { Extru. speed }\end{array}$} & \multirow{2}{*}{$\begin{array}{l}X_{3} \\
\text { PVP K } 30\end{array}$} & \multirow{2}{*}{$\begin{array}{l}Y_{1} \\
\text { Carr's index }\end{array}$} & \multirow{2}{*}{$\begin{array}{l}Y_{2} \\
\% y i e l d\end{array}$} & \multirow{2}{*}{$\begin{array}{l}Y_{3} \\
T_{50 \%}\end{array}$} & \multirow{2}{*}{$\begin{array}{l}\mathrm{Y}_{4} \\
12 \mathrm{~h} \text { drug release }\end{array}$} \\
\hline & $\mathbf{X}_{1}$ & $\mathbf{X}_{2}$ & $\mathbf{X}_{3}$ & $\begin{array}{l}\text { Sph. } \\
\text { speed }\end{array}$ & & & & & & \\
\hline R1 & -1 & -1 & -1 & 900 & 45 & $1.50 \%$ & $3.195 \pm 0.1$ & $54.5 \pm 2.1$ & 6.30 & $79.843 \pm 4.2$ \\
\hline $\mathrm{R} 2$ & 1 & -1 & -1 & 1400 & 45 & $1.50 \%$ & $0.481 \pm 0.0$ & $59.8 \pm 3.2$ & 8.0 & $79.109 \pm 3.4$ \\
\hline R3 & -1 & 1 & -1 & 1400 & 55 & $1.50 \%$ & $0.368 \pm 0.0$ & $48 \pm 2.4$ & 8.0 & $82.060 \pm 4.8$ \\
\hline $\mathrm{R} 4$ & 1 & 1 & -1 & 1400 & 55 & $1.50 \%$ & $0.651 \pm 0.1$ & $65.8 \pm 3.1$ & 7.30 & $76.117 \pm 1.4$ \\
\hline R5 & -1 & -1 & 1 & 900 & 45 & $3.00 \%$ & $2.098 \pm 0.2$ & $49.8 \pm 3.0$ & 7.0 & $81.897 \pm 5.3$ \\
\hline R6 & 1 & -1 & 1 & 900 & 45 & $3.00 \%$ & $4.361 \pm 0.4$ & $67.85 \pm 2.9$ & 8.0 & $80.781 \pm 5.1$ \\
\hline R7 & -1 & 1 & 1 & 900 & 55 & $3.00 \%$ & $5.281 \pm 0.2$ & $69.6 \pm 3.4$ & 8.0 & $83.142 \pm 4.9$ \\
\hline R8 & 1 & 1 & 1 & 1400 & 55 & $3.00 \%$ & $3.541 \pm 0.3$ & $59.5 \pm 2.4$ & 8.30 & $73.446 \pm 4.1$ \\
\hline
\end{tabular}

$\mathrm{X}_{1}$ : Spheronization speed; $\mathrm{X}_{2}$ :Extrusion speed; $\mathrm{X}_{3}$ :PVP K30 conc. The response carr's index $\left(\mathrm{Y}_{1}\right),\left(\mathrm{Y}_{2}\right) \%$ yield, $\left(\mathrm{Y}_{3}\right)$ time required to release $50 \%$ drug and $\left(Y_{4}\right) \%$ of drug release in $12 \mathrm{~h}$. Data are presented as mean $\pm S D(n=3)$ 


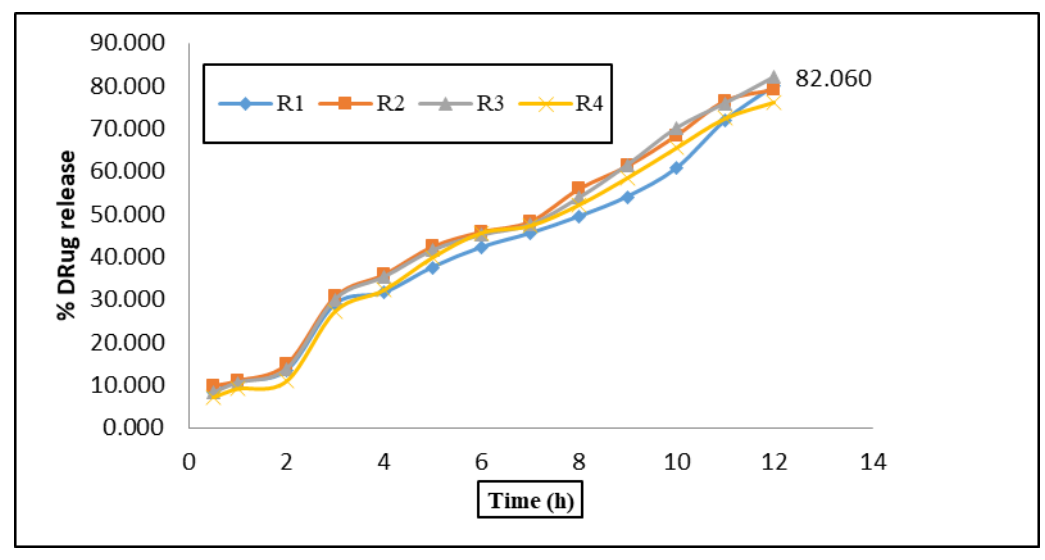

Fig. 5: Percent drug release in $12 \mathrm{~h}(\mathrm{R} 1-\mathrm{R} 4)$, data are presented as mean $\pm \operatorname{SD}(\mathrm{n}=3)$

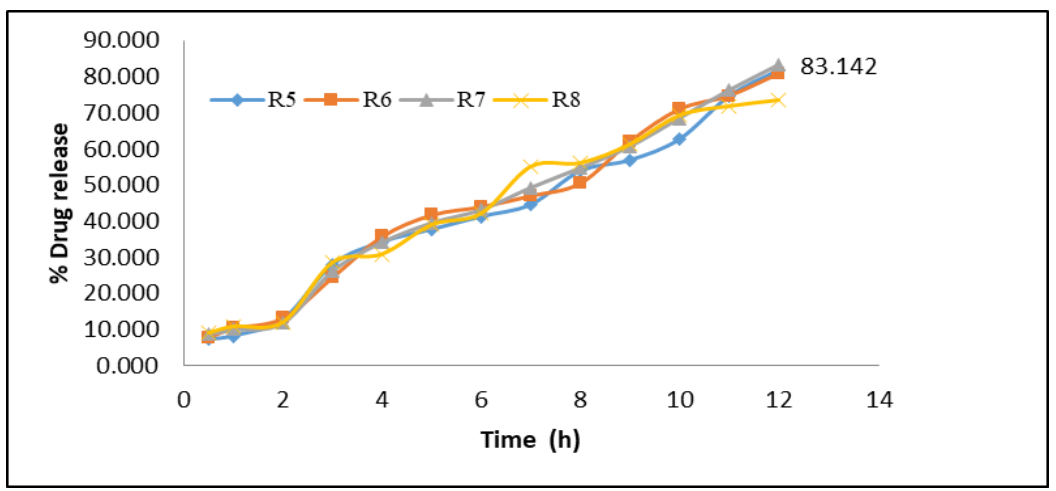

Fig. 6: Percent drug release in $12 \mathrm{~h}(\mathrm{R} 5-\mathrm{R} 8)$, data are presented as mean $\pm S D(n=3)$

\section{Statistical analysis for Y1, Y2, Y3 and Y4}

Statistical analysis of the design was carried out by using registered Design Expert 8 (Stat Ease Inc. Minneapolis USA). The obtained data were fitted in the Design Expert Software to analyze different statistical parameters. The statistical analysis model explaining the effect of various factors on response surface methodology RSM of output variables like carr's index, $\%$ yield, $\mathrm{T}_{50 \%}$ (time required to release $50 \%$ of the drug) and \% drug release in $12 \mathrm{~h}$. The optimum preparations were selected. Optimum preparation was picked by the critical evaluation. The criteria for selection of optimum preparations is primarily based on maximum drug release at $12 \mathrm{hr}$. 3FI model is studied for Y1, Y2, Y3 and Y4 in detail to established the DS.

For Y1 (carr's index) the 3 factor interaction (3FI) was found to be best fit model and polynominal equation is given below.
Y1 (Carr's index) $=+2.50-0.24 \mathrm{X}_{1}-0.037 \mathrm{X}_{2}+1.32 \mathrm{X}_{3}-$ $0.13 \mathrm{X}_{1} \mathrm{X}_{2}+0.37 \mathrm{X}_{1} \mathrm{X}_{3}+0.63 \mathrm{X}_{2} \mathrm{X}_{3}-0.88 \mathrm{X}_{1} \mathrm{X}_{2} \mathrm{X}_{3}$ are in $3 \mathrm{D}$ plot in fig. 7.

$\mathrm{Y} 2$ (percentage yield) $=+59.36+3.88 * \mathrm{X}_{1}+1.37 * \mathrm{X}_{2}+2.33 * \mathrm{X}_{3}-1.96 * \mathrm{X}_{1} \mathrm{X}_{2}$ $1.89 * \mathrm{X}_{1} \mathrm{X}_{3}+{ }^{*} \mathrm{X}_{2} \mathrm{X}_{3}-5.08 * \mathrm{X}_{1} \mathrm{X}_{2} \mathrm{X}_{3}$ is given in 3D graph fig. 8 .

It shows that $\mathrm{X}_{3}$ (PVP K30) has shown a positive effect on and $\mathrm{X}_{1}$ (Spheronization speed) shown negative effect flow properties of pellets that is carr's index. Increases with interaction with $\mathrm{X}_{3} \mathrm{X}_{1}$ spheronization speed and PVP K30 give a good carr's index and have a positive impact on the flow properties of pellets shown in fig. 7 . The response surface for \% yield was studied by polynomial equation by $3 \mathrm{FI}$ interaction it was seen that increasing the $\mathrm{X}_{1}$ and $\mathrm{X}_{2}$ i.e. spheronization speed and extrusion speed gives good and positive impact on \% yield up to $69 \%$. The DS was achieved within the value. As shown in fig. 8. 3D plot.

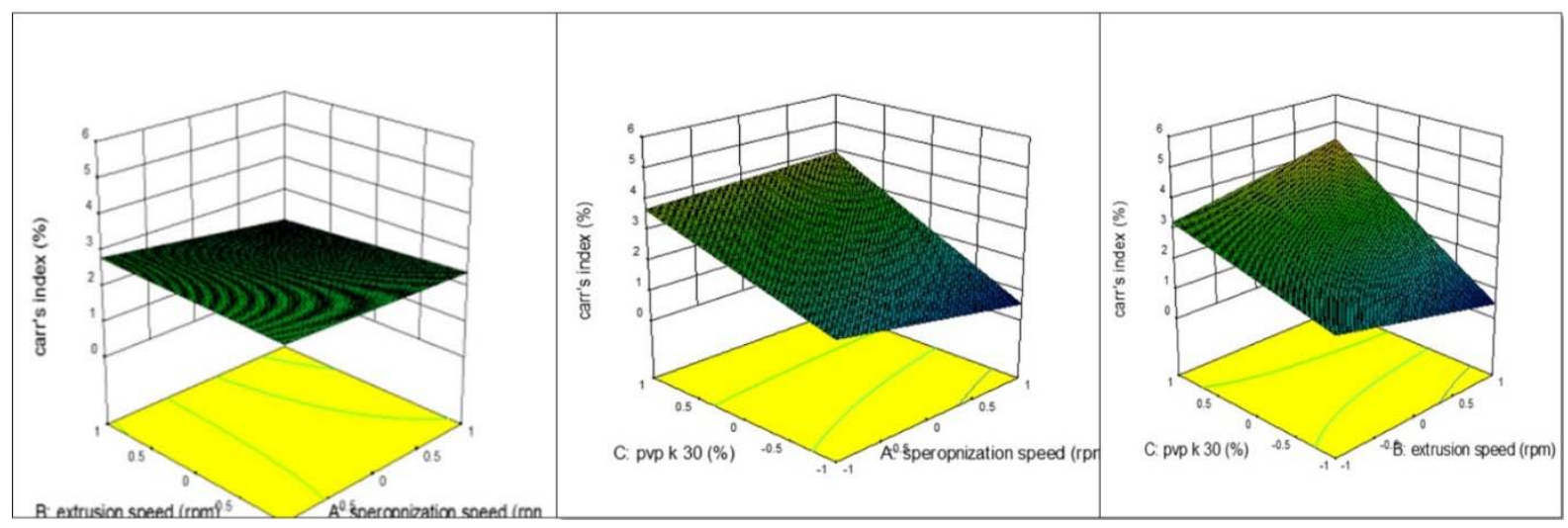

Fig. 7: 3D response surface plot for Carr's index $\left(Y_{1}\right)$ 

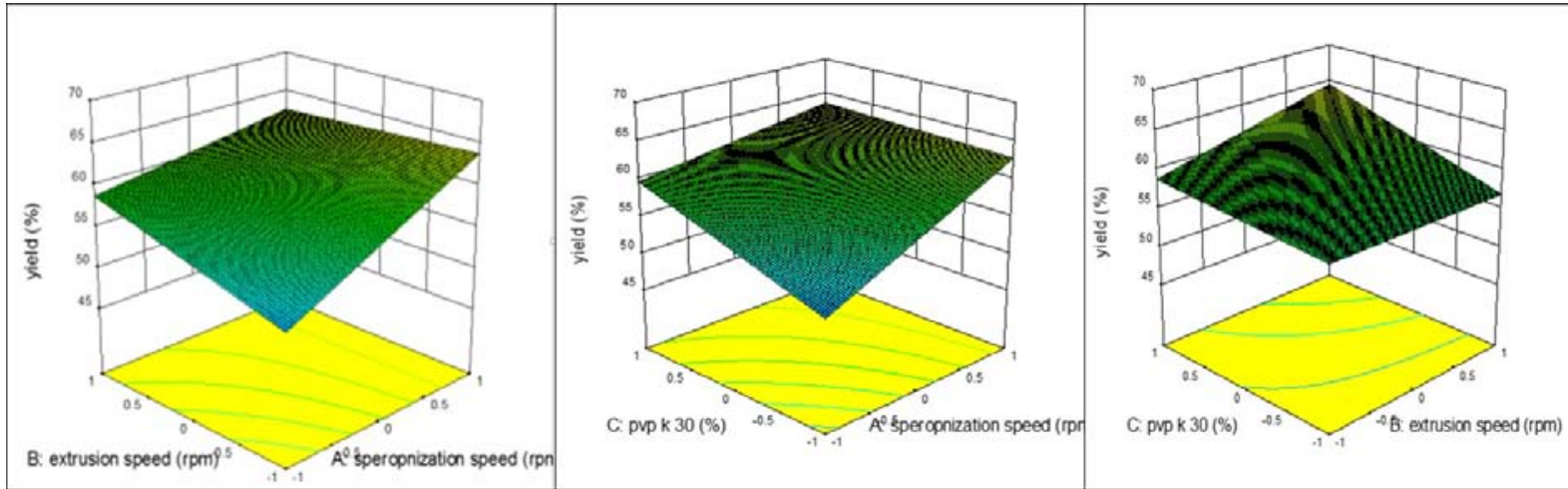

Fig. 8: 3D response surface plot for percentage yield $\left(\mathrm{Y}_{2}\right)$
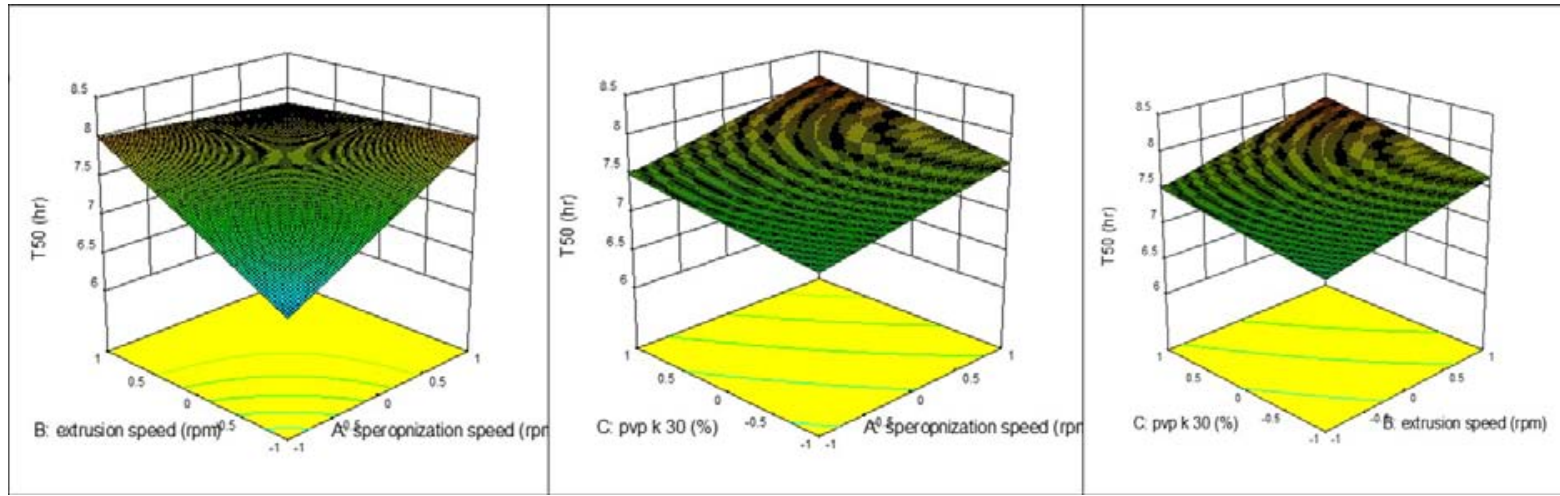

Fig. 9: 3D response surface plot for time required to release $50 \%$ drug $\left(Y_{3}\right)$

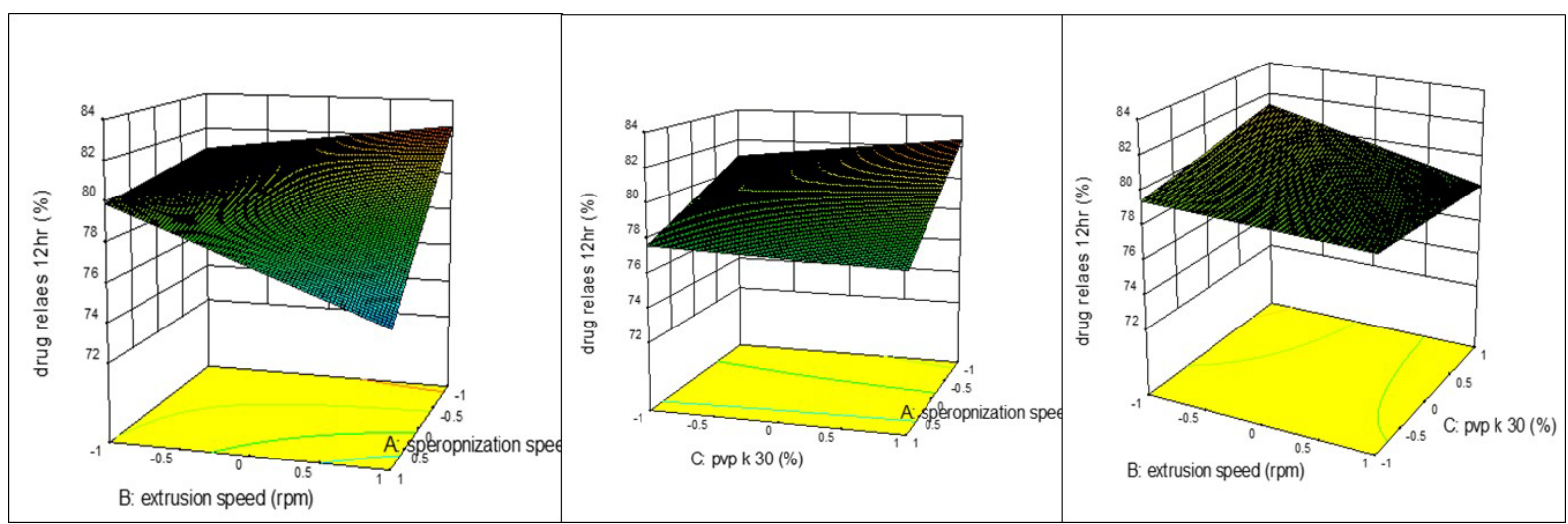

Fig. 10: 3D response surface plot for percent drug release $\left(Y_{4}\right)$

Based on the response surface model. For the third response, all three factors had shown positive effect on response. As the binder concentration increases the time required for release the $50 \%$ drug is improved plot as shown in fig. 9. For the response percent drug release. Binder concentration PVP K30 has positive effect on drug release. As the PVP K30 increases, the dissolution also improved. Extrusion speed and spheronization speed had shown same positive impact on the dissolution profile. The DS was achieved within the value as shown in fig. 10 . The drug release was achieved at the range of $83.142 \pm 4.19$ in $3 \mathrm{D}$ plot. The $\mathrm{Y} 1$ was found to be $5.281 \pm 0.2$ as a good carr's index for batch R7, percentage yield found $69.6 \pm 3.4 \%$, time required to release $50 \%$ drug found to be $8 \mathrm{~h}$, percent drug release was found $83.142 \pm 4.9 \%$ so from all the four responses batch R7 was found to be best batch and selected as optimized batch.

\section{Development of control strategy for ritonavir sustained-release} pellets

The process control was determined on the carr's index $(\mathrm{Y} 1<10)$, \%yield (Y2>70\%), $\mathrm{T}_{50 \%}(\mathrm{Y} 3>8 \mathrm{~h})$ and \% drug release $(>80 \%)$. According to the result of Plackett-Burman design and $2^{3}$ factorial design, the final control space was defined in detail in table 5. Spheronization speed (1200rpm), Spheronization time (20 min), extrusion speed (55rpm) and PVP K $30(3.0 \%)$. In order to define the final control space, one formulation parameter was range to the final control space that is R7. Design space includes the control strategy. in which three factors were performed in $2^{3}$ factorial design as final process for pellets by extrusion spheronization which are CPPs and CMAs from CQAs [12, 22]. 
Table 5: Control strategy for ritonavir sustained released pellets

\begin{tabular}{|c|c|c|c|c|}
\hline Factor & $\begin{array}{l}\text { Attributes or } \\
\text { parameters }\end{array}$ & $\begin{array}{l}\text { Range studied } \\
\text { (lab scale) }\end{array}$ & Justification for range & Purpose of control \\
\hline \multicolumn{5}{|c|}{ Critical Material Attributes } \\
\hline Povidone K-30 & Binder \% & $3.0 \%-7.0 \%$ & Optimization range studied & To ensure batch to batch consistency \\
\hline \multicolumn{5}{|c|}{ Critical Process Parameters } \\
\hline Pellets Process & \multirow[t]{2}{*}{ Extrusion speed } & Time: $10 \mathrm{~min}$ & \multirow[t]{5}{*}{ Optimization range studied } & \multirow{5}{*}{$\begin{array}{l}\text { To ensure all pellets CQAs (Yield, flow } \\
\text { properties, Dissolution) are met consistently }\end{array}$} \\
\hline Parameter & & Speed: $55 \mathrm{rpm}$ & & \\
\hline & \multirow{3}{*}{$\begin{array}{l}\text { Spheronization } \\
\text { speed } \\
\text { Mixing }\end{array}$} & Time: $20 \mathrm{~min}$ & & \\
\hline & & Speed: $1400 \mathrm{rpm}$ & & \\
\hline & & Time: $15 \min$ & & \\
\hline \multicolumn{5}{|c|}{ Drying Process Parameters } \\
\hline \multirow[t]{2}{*}{$\begin{array}{l}\text { Drying parameter } \\
\text { of Pellets }\end{array}$} & Hot oven & $110^{\circ} \mathrm{C}$ & Optimization range studied & $\begin{array}{l}\text { To ensure batch to batch reproducibility for PSD } \\
\text { of pellets, flowability, Dissolution }\end{array}$ \\
\hline & Drying time & $10 \mathrm{~min}-20 \mathrm{~min}$ & Optimization range studied & $\begin{array}{l}\text { To ensure batch to batch reproducibility pellets } \\
\text { properties like PSD }\end{array}$ \\
\hline \multicolumn{5}{|c|}{ Extrusion spheronization pellets In-Process Controls } \\
\hline \multirow{2}{*}{$\begin{array}{l}\text { Individual weight } \\
\text { Hardness }\end{array}$} & \multirow{2}{*}{\multicolumn{2}{|c|}{$\begin{array}{l}500.0 \mathrm{mg} \pm 5.0 \% \\
\text { Limits: } 0.365 \mathrm{~kg} / \mathrm{cm}^{2} \pm 5 \\
\mathrm{~kg} / \mathrm{cm}^{2}\end{array}$}} & \multirow{6}{*}{$\begin{array}{l}\text { Parameter fixed based on lab } \\
\text { scale development experience }\end{array}$} & \multirow{6}{*}{$\begin{array}{l}\text { To ensure all pellets CQAs (Drug content, } \\
\text { Dissolution) are met consistently. }\end{array}$} \\
\hline & & & & \\
\hline Particle size & \multicolumn{2}{|c|}{ Limits: $1 \mathrm{~mm} \pm 0.5 \mathrm{~mm}$} & & \\
\hline Friability & \multicolumn{2}{|c|}{ NMT $1.0 \%$} & & \\
\hline Spheronization speed & \multicolumn{2}{|c|}{ 1400rmp } & & \\
\hline Extrusion speed & \multicolumn{2}{|c|}{$55 \mathrm{rmp}$} & & \\
\hline
\end{tabular}

\section{CONCLUSION}

QbD is an essential part of the modern approach to pharmaceutical quality. This current study demonstrated how QbD approach can be applied toward the development of a formulation of ritonavir SR pellets. This study teaches the use of QbD including an emphasis on the importance of the target product quality profile in a quantitative performance target for QbD. Fish-bone diagram and FMEA analysis were used to identify critical formulation and process parameters that affect ritonavir sustained-release pellets product quality. Next, the Plackett-Burman and $2^{3}$ factorial design were used for screening the significant factors and optimizing the variables range, respectively. The final aim of this approach to achieve Design space. Lastly control strategy was defined. It could be concluded that sustained-release pellets were successfully designed using QbD approach.

\section{AUTHORS CONTRIBUTIONS}

All the authors have contributed equally.

\section{CONFLICTS OF INTERESTS}

The authors declare no conflicts of interest.

\section{REFERENCES}

1. Sonar G, Rawat S. Optimization of pantoprazole enteric pellets coating process by qbd: effect of coating process variables on the intermediate quality of the product and scale-up. Int J Pharm Pharm Sci 2015; 7:80-7.

2. Patil AS, Pethe AM. Quality by design (Qbd): a new concept for the development of quality pharmaceuticals. Int J Qual Assur 2013;4:13-9.

3. Gawade A, Chemate S, Kuchekar A. Pharmaceutical quality by design: a new approach in product development. Res Rev: J Pharm Pharm Sci 2013;2:1-8.

4. Roy S. Quality by design: a holistic concept of building quality in pharmaceuticals. Int J Pharm Biomed Res 2012;3:100-8.

5. Lawrence XY. Pharmaceutical quality by design: product and process development, understanding, and control. Pharm Res 2008;25:781-91.

6. Jain S. Quality by design (Qbd): a comprehensive understanding of implementation and challenges in pharmaceuticals development. Int $\mathrm{J}$ Pharm Pharm Sci 2014;6:29-35.

7. Wang J, Kan S, Chen T, Liu J. Application of quality by design (Qbd) to the formulation and processing of naproxen pellets by extrusion-spheronization. Pharm Dev Technol 2015;20:24656.

8. Sirisha VR, Sri KY, Suresh K, Reddy Gk, Devanna N. A review of pellets and pelletization process-a multiparticulate drug delivery system. Int J Pharm Sci Res 2013;4:2145.

9. Kandukuri JM, Allenki V, Eaga Cm, Keshetty V, Jannu KK. Pelletization techniques for oral drug delivery. Int J Pharm Sci Res 2009;1:63-70.

10. Patil KJ, Sarode SM. Formulation and evaluation of sustainedrelease tablet of ritonavir. World J Pharm Pharm Sci 2014;3:854-69.

11. Kaljevic O, Djuris J, Djuric Z, Ibric S. Application of failure mode and effects analysis in quality by design approach for formulation of carvedilol compression coated tablets. J Drug Delivery Sci Technol 2016;32:56-63.

12. Us Food and Drug Administration. Quality By Design For Ands: An Example For Modified-Release Dosage Forms; 2011.

13. Sona PS, C Muthulingam, G Geetha. Preparation of pellets of bosentan by extrusion spheronizationscreening study of process parameters by plackett-burman design. Int J Pharm Life Sci 2012;2:88-97.

14. Dua $S$, Mahant $S$, Tiwari R. Influence of process and formulation variables on physical properties of the pellets using a $2^{3}$ factorial design. Int J Pharm Sci Rev Res 2011;7:47-50.

15. Puranik PK, Khan FM. Formulation and evaluation of aceclofenac loaded sr matrix pellets: extrusion spheronization. Int J Pharm Pharm Sci 2013;5:781-9.

16. Upasani A, Kshirsagar S, Bhalekar M. Design and optimization of sustained release matrix tablet of opipramol hcl by using quality by design approach. Asian J Pharm Clin Res 2014;7:22434.

17. Kumar KS, Bhowmik D, Srivastava S, Paswan S, Dutta As. Sustained-release drug delivery system potential. Pharma Innovation 2012;1:48-60.

18. Zameeruddin M, Namdev H, Jadhav SB, Kadam VS, Bharkad VB, Anil B. Recent advances of sustained-release oral drug delivery system: a review. Int J Pharm Sci Biomed Sci 2014;3:1479-89.

19. Lavanya K, Senthil V, Rathi V. Pelletization technology: a quick review. Int J Pharm Sci Res 2011;2:1337.

20. Jezerska L, Zajonc O, Vyletelek J, Zegzulka J. Mechanical material properties effect on pelletization. Wood Res 2016;61:307-20.

21. Singh G, Pai RS, Devi VK. Optimization of pellets containing solid dispersion prepared by extrusion/spheronization using central composite design and desirability function. J Young Pharm 2012;4:146-56. 
22. S SY, V SS, N KR. Formulation optimization of promethazine theoclate immediate release pellets by using the extrusionspheronization technique. Int J Appl Pharm 2018;10:30-5.
23. Desai S, J Disouza, K Musle, H Avinash. Solubility enhancement of ritonavir by hot melt extrusion. Int J Pharm Pharm Sci 2016;8:309-12. 